\title{
Environmental biological model based on optimization of activated sludge process
}

\author{
${ }^{1 *}$ X. X. Zhang; ${ }^{1}$ D. Y. Zhao; ${ }^{1}$ Z. X. Wang; ${ }^{1}$ B. Wu; ${ }^{1,2}$ W. X. Li; ${ }^{1}$ S. P. Cheng \\ ${ }^{1}$ State Key Laboratory of Pollution Control and Resource Reuse, School of the Environment, Nanjing University, \\ Nanjing, 210093, China \\ ${ }^{2}$ Nanjing Institute of Environmental Sciences, State Environmental Protection Administration of China, Nanjing, \\ 210042, China \\ Received 27 May 2008; $\quad$ revised 14 August 2008; accepted 25 November 2008; available online 10 December
}

\begin{abstract}
A simplified environmental biological model has been developed based on biodegradation kinetics correlation to regulate and optimize wastewater treatment system of activated sludge process. All parameters included in the model are calibrated in accordance with reference data and experimental results and good agreements are achieved between calculated results and reference data or experimental results. The minimum bioreactor volume is used as objective function in the model and errors between optimal minimum volume of the model and each reported result of three references are found to be no more than $8.63 \%$ after validation. Comparisons between optimal results and experimental data demonstrate that the deviations are negligible. The optimal minimum volume is $9.21 \mathrm{~m}^{3}$ with the error of $6.40 \%$ to the practical bioreactor volume of a pilot treatment system. The environmental biological model has been applied to economically evaluate a former treatment system with native bacterium YZ1 and four operation periods of the pilot system with functional strain Fhhh compared with YZ1, Fhhh possesses higher biodegradation ability in purified terephthalic acid wastewater and a broader economic potential in the field of wastewater treatment.
\end{abstract}

Keywords: Cost evaluation, functional strain, mathematical model, wastewater treatment, biodegradation kinetics

\section{INTRODUCTION}

With rapid development of informatics technology, many advanced informatics methods have been introduced to the field of environmental pollution control (Cheng et al., 2002; Glover et al., 2006). In order to solve environmental problems more effectively, researchers are focusing on design and optimization of the control processes for environmental pollution through imitation and simulation of these problems (Zeidan et al., 2003; Templeton et al., 2006; Li et al., 2008; Rashidinejad et al., 2008). Development of informatics techniques, including mathematical modeling (Panjeshahi and Ataei, 2008), artificial neural network (Choi and Park 2001), fuzzy control (Chen and Chang, 2008), database construction (Okubo et al., 1994) and expert system (Ribas et al., 2008) has been one of the most exciting progresses in wastewater treatment technology in recent years.

International wastewater association (IWA) Task Group proposed activated sludge model No. 1(ASM1) in 1987, activated sludge model No. 2 (ASM2) in 1994

\footnotetext{
\*Corresponding Author Email: zhangxx@nju.edu.cn
} Tel.: +8625 8359 5995; Fax: +8625 83595995 and activated sludge model No. 3 (ASM3) in 1999 (IWA Task Group, 2000) which has made major contributions to promote numerical analyses in wastewater treatment. The methods of the parameter estimation and calibration procedures have been presented for the ASMs (Von Sperling, 1994; Reichert et al., 1995; Mino et al., 1997). Optimal operating modes for biofilm process and sequencing batch reactors were also determined via model based optimization (Suzuki et al., 1999; Souza et al., 2008). Some models have been developed for optimization of removing nitrogen or other toxic chemicals in activated sludge reactors (Oda et al., 2006; Hu et al., 2007; Rivas et al., 2008).

In those models, main attention was paid to seek reasonable models to simulate activated sludge process by mathematical or informatics techniques, but microbial effects were neglected (Gujer, 2006). Lack of recognition of microbial crucial roles in bioreactors makes the models less reliable, even when heterogenous or functional microorganisms are introduced into bioreactors to improve operation efficiency. However, the problem can be solved with 
microbial degradation kinetics which deals with the relationship between microbial growth rate and pollutant degradation rate, as well as the effects of environmental factors on the microbial growth and pollutant removal (Hosseini et al., 2007; Mohanan et al., 2007).

Different from the above methods, in this paper an environmental biological model (EBM) is developed with the special attention paid to biodegradation kinetics parameters which can reflect the biodegradation and adaptation abilities of various microorganisms in different wastewaters. The aims of this work are:

1. Regulate and optimize wastewater treatment system of activated sludge process with the simplified model based on biodegradation kinetics correlation;

2. Comparatively assess the treatment system of purified terephthalic acid (PTA) wastewater with functional strains cultivated in the bioreactor which was operated in Nanjing Yangtze wastewater treatment plant (Nanjing, China) from 2002 to 2004.

\section{MATERIALS AND METHODS}

Mathematical equations and parameters

EBM optimization and evaluation function is achieved based on activated sludge process. The flow sketch and related parameters are shown in Fig. 1. The validity of mathematical equations depends on its reasonability.

EBM is developed based on biodegradation kinetics and mass balance theory and the methods are described in detail in Table 1. Total twenty eight mathematical equations (divided into four groups) are employed to develop EBM and the equations are set up with the following suppositions:

1. EBM is proposed with $\mathrm{V}_{\text {min }}$ as objective function and $\mathrm{V}_{\text {min }}$ errors between EBM computed results and reference or experimental data are considered as the main evaluation factors for the model validity;
2. The mathematical equations of wastewater treatment process and the relationship between objective function and process parameters are achieved with $\mathrm{Q}_{\mathrm{r}}, \mathrm{S}_{\mathrm{e}}$ and $\mathrm{X}_{\mathrm{e}}$ as recycled variables according to mass balance theory and Monod equations (Qin, 1989);

3. It is thought that there is no effective biomass in the bioreactor influent wastewater based on the facts of high toxicity induced by PTA wastewater and very few microorganisms living in the wastewater (Zhang et al., 2005).

4. According to reported data from references, some coefficients of the mathematical equations such as $\lambda_{1}, \lambda_{2}$, $\gamma_{1}$ and $\gamma_{2}$ have been determined for cost evaluation (Middleton and Lawrence, 1974; Gu, 1993).

Forty eight variables used in EBM equations are divided into eight groups:

1. Optimization computation objective function $\mathrm{V}_{\text {min }}$;

2. Degradation kinetics parameters, including $\mathrm{q}_{\max }, \mu_{\max }$, $\mathrm{K}_{\mathrm{sq}}, \mathrm{K}_{\mathrm{si}}, \mathrm{K}_{\mathrm{d}}$ and $\mathrm{Y}_{\mathrm{t}}$;

3. Natural parameters of water quality, including $Q_{0}, S_{0}$ and $\mathrm{X}$;

4. Wastewater treatment process parameters, including HRT, $\mathrm{M}_{\mathrm{t}}, \mathrm{Q}_{\mathrm{e}}, \mathrm{q}, \mathrm{Q}_{\mathrm{s}}$, SRT, SVI, V, X, $\mathrm{X}_{\mathrm{r}}, \mathrm{X}_{\mathrm{s}}, \mathrm{Y}_{\mathrm{obs}}$ and $\mu$;

5. Recycled variables, including $\mathrm{Q}_{\mathrm{r}}, \mathrm{S}_{\mathrm{e}}$ and $\mathrm{X}_{\mathrm{e}}$;

6. Control parameters of water quality, including $\mathrm{S}_{\mathrm{e}}$ and $\mathrm{X}_{\mathrm{ei}}$;

7. Conventional experienced coefficient, including $\mathrm{C}_{\mathrm{sm}(20)}$, $\mathrm{E}_{\mathrm{A}}, \mathrm{K}_{\mathrm{L}} \mathrm{a}_{(20)}, \alpha, \beta, \lambda_{1}, \lambda_{2}, \gamma_{1}, \gamma_{2}$ and

8. Cost evaluation parameters, including $A_{T}, C, E_{e}, E_{f}$, $\mathrm{G}_{\mathrm{s}}, \mathrm{R}, \mathrm{T}_{\mathrm{d}}, \mathrm{T}, \mathrm{V}_{\mathrm{d}}, \mathrm{V}_{\mathrm{s}}$ and ZSV.

\section{Operation strategy and programming}

EBM optimization computation is achieved through recycle operation of computer. The model has been programmed with Visual Basic 7.0 language (Microsoft Co., USA). EBM operation strategies are described as following:

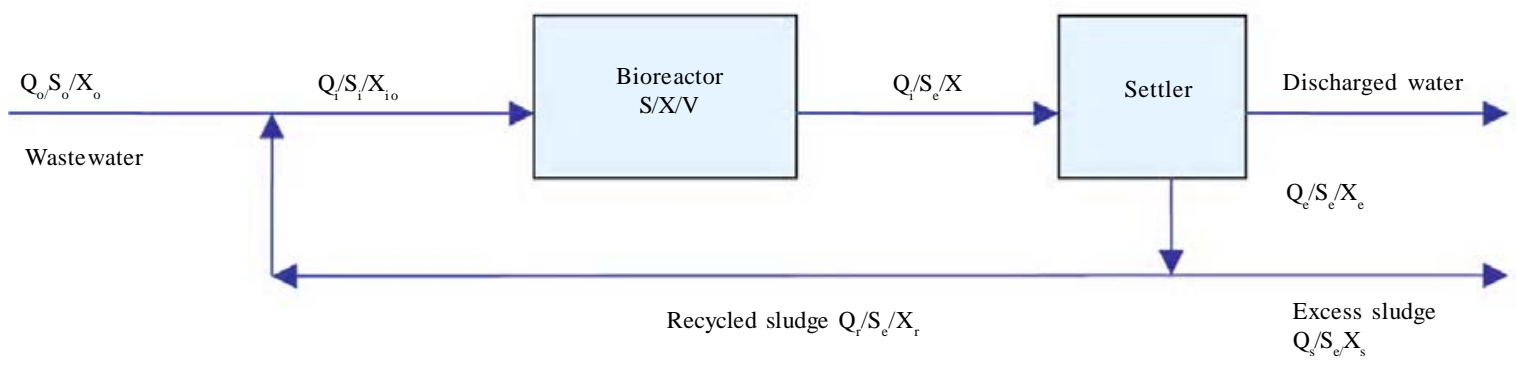

Fig. 1. Flow sketch of conventional activated sludge process 
Int. J. Environ. Sci. Tech., 6 (1), 69-76, Winter 2009

Table 1: Mathematical equations of environmental biological model (EBM)

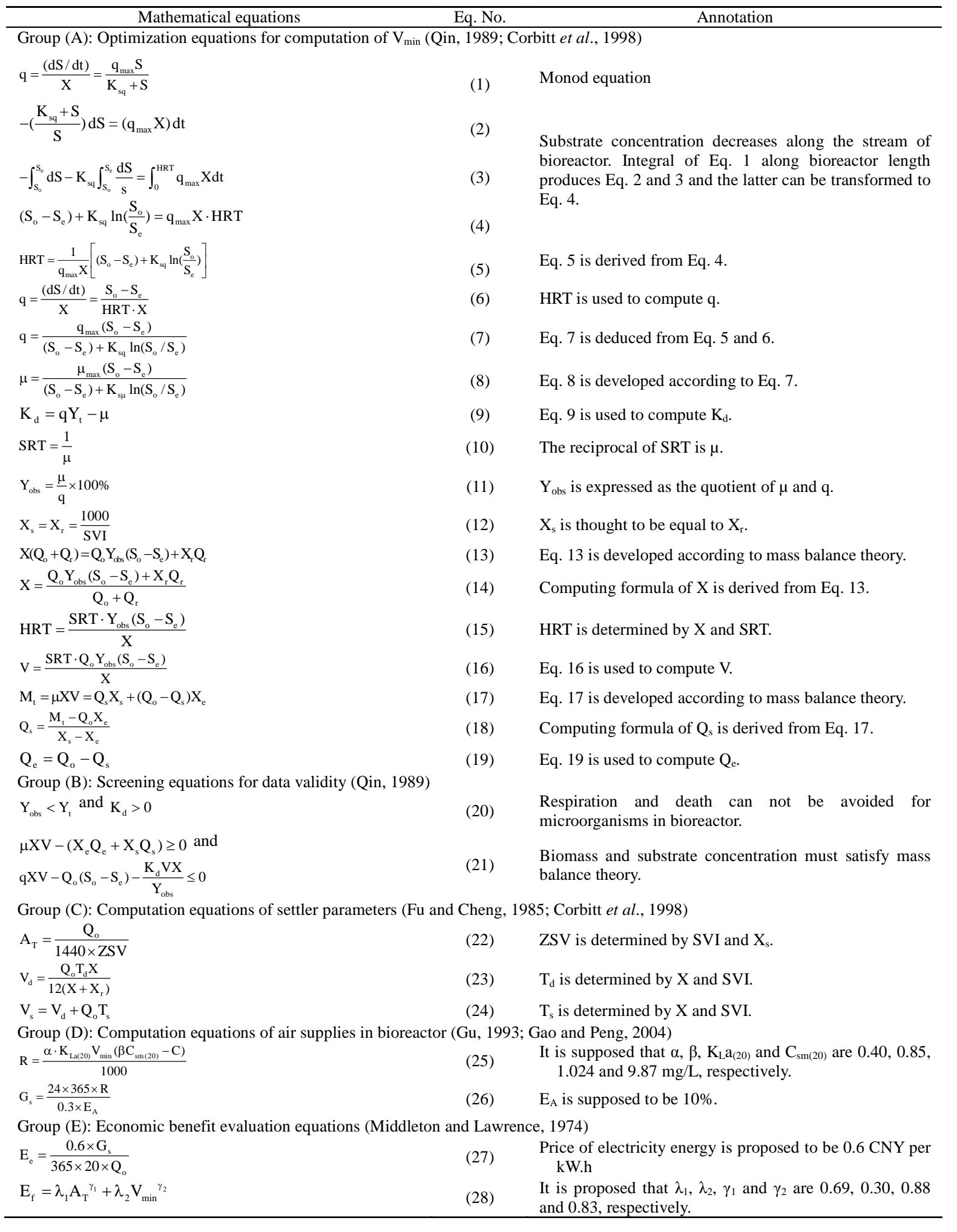


1. After input of the values of ten parameters $\left(\mathrm{q}_{\max }, \mathrm{K}_{\mathrm{sq}}\right.$, $\mu_{\text {max }}, K_{s \mu}, Y_{t}, S V I, Q_{o}, S_{o}, S_{e i}$ and $X_{e i}$ ) into EBM, corresponding calculation of $\mu, q, \theta_{c}, K_{d}$ and $Y_{\text {obs }}$ will be carried out with $\mathrm{S}_{\mathrm{e}}$ as recycled variable;

2. The produced data arrays must be verified with Eq. 20 on account of microbial respiration and death which are inevitable during the growth. With $\mathrm{S}_{\mathrm{e}}, \mathrm{X}_{\mathrm{e}}$ and $\mathrm{Q}_{\mathrm{o}}$ as recycled variables, the eligible data arrays can be used to calculate the matrix including, $X, X_{s}, X, \theta, V, M, Q_{0}$ and $Q_{e}$;

3. The results in the matrix must be screened with Eq. 21 for mass balance verification. If no data arrays in the matrix can satisfy the condition, it demonstrates that no optimal result is produced by EBM in the wastewater treatment system;

4. However, in the case of more than one eligible data array , the array with the minimum volume of bioreactor can be assigned to be the optimal result $\left(\mathrm{V}_{\text {min }}\right)$. The corresponding recycled variables $\left(S_{e}, X_{e}\right.$ and $\left.Q_{0}\right)$ are also obtained in the optimal data array. Original and final values and steps of the three variables are shown in Table 2;

5 . Subsequently, equations in group (C) can be employed to calculate related parameters of settlers based on the values of $Q_{0}, X, X_{r}$ and SVI in the optimal data array and those in group (D) are used for determination of R and $G_{s}$ based on $\mathrm{V}_{\text {min }}$ value;

6. After the values $\mathrm{G}_{\mathrm{s}}, \mathrm{A}_{\mathrm{T}}$ and $\mathrm{V}_{\text {min }}$ are obtained, calculation for $\mathrm{E}_{\mathrm{f}}$ and $\mathrm{E}_{\mathrm{e}}$ can be performed with equations in group (E) to evaluate the wastewater treatment systems economically.

\section{RESULTS AND DISCUSSION}

\section{Calibration with reference data}

Comparisons between EBM optimal results and the reference data have been performed. The reference data of twenty two operational parameters was obtained from different wastewater treatment systems with activated sludge process (Lee and Lin, 1999; Qin, 1989; Woodard, 2001). Ten reference data $\left(q_{\max }, K_{s q}, \mu_{\max }, K_{s \mu}, Y_{t}, S V I, Q_{o}\right.$, $\mathrm{S}_{\mathrm{o}}, \mathrm{S}_{\mathrm{ei}}$ and $\mathrm{X}_{\mathrm{ei}}$ ) have been input into EBM on the interface (Table 3) and the optimal values of other sixteen parameters $\left(S_{e}, X_{e}, X, X_{s}, X_{r}, H R T, V_{\text {min }}, M_{t}, Q_{r}, Q_{s}, Q_{e}, \mu, q, S R T, K_{d}\right.$ and $\mathrm{Y}_{\mathrm{obs}}$ ) are produced on output interface of the software(Table

Table 2: Original and final value and step of EBM recycled variables

\begin{tabular}{llll}
\hline $\begin{array}{l}\text { Recycled } \\
\text { variable }\end{array}$ & $\begin{array}{l}\text { Original } \\
\text { value }\end{array}$ & Final value & Step \\
\hline $\mathrm{S}_{\mathrm{o}}$ & $0.01 \mathrm{~S}_{\mathrm{o}}$ & $\mathrm{S}_{\mathrm{o}}$ & $0.01 \mathrm{~S}_{\mathrm{o}}$ \\
$\mathrm{S}_{\mathrm{e}}$ & $0.01 \mathrm{~S}_{\mathrm{ei}}$ & $\mathrm{S}_{\mathrm{ei}}$ & $0.01 \mathrm{~S}_{\mathrm{ei}}$ \\
$\mathrm{Q}_{\mathrm{r}}$ & $0.01 \mathrm{Q}_{\mathrm{o}}$ & $1.99 \mathrm{Q}_{\mathrm{o}}$ & $0.01 \mathrm{Q}_{\mathrm{o}}$ \\
\hline
\end{tabular}

3). After comparisons between EBM optimal results and reference data, the differences of most parameters, including $\mathrm{V}_{\text {min }}$, HRT, SRT and $\mathrm{Q}_{\mathrm{r}}$ between the two groups are not significant and can be negligible. The $\mathrm{V}_{\min }$ errors between the EBM optimal results and the reported data from the three references are $4.44 \%, 8.63 \%$ and $5.93 \%$, respectively. It is found that EBM exhibits a high validity when it is used for optimization computation of wastewater treatment system.

Pollutant removal efficiency of activated sludge process depends on wastewater components (various pollutants and different concentrations) and species or characteristics of microorganisms in bioreactor (Gujer et al., 1999). The different wastewater conditions and structural variations of microbial communities make the kinetic parameters $\left(\mathrm{q}_{\max }, \mathrm{K}_{\mathrm{sq}}, \mu_{\max }, \mathrm{K}_{\mathrm{sp}}, \mathrm{Y}_{\mathrm{t}}\right.$ and $\left.\mathrm{K}_{\mathrm{d}}\right)$ vary greatly in the three examples (Table 3). EBM is a mathematical model developed according to the principle that operational parameters must be adjusted with the changes of wastewater characteristics and biodegradation kinetic parameters which makes a great contribution to EBM validity.

\section{Calibration with experimental results}

To calibrate the EBM with experimental results, PTA wastewater was subject to biodegradation kinetics test to quantify the six parameters, including $q_{\max }, K_{s q}, \mu_{\max }$, $\mathrm{K}_{\mathrm{s} \mu}, \mathrm{Y}_{\mathrm{t}}$ and $\mathrm{K}_{\mathrm{d}}$. Degradation kinetic experiments were carried out according to Cheng et al. (2003). PTA wastewater was treated with activated sludge process (Fig. 1). Functional strain Fhhh constructed through protoplast fusion with the three parental strain of Phanerochaete chrysosporium, Saccharomyces cerevisiae and native bacterium Bacillus YZ1 at laboratory, was cultivated in bioreactor at Nanjing Yangtze wastewater treatment plant (Nanjing, China) to improve the removal efficiency of pollutants in PTA wastewater (Hao et al., 2003; Sun et al., 2005; Zhang et al., 2006a). The treatment system with bioreactor effective volume of $9.84 \mathrm{~m}^{3}$ was operated continuously and stably for more than 180 days in the plant. According to regulation strategies (Table 4), the treatment system was regulated and optimized in terms of process parameters, metallic ions and nutrition factors and also the whole operation time was divided into four periods. The experimental results of biodegradation kinetic parameters and operational parameters in the pilot treatment system have been shown in Table 5. EBM optimal results are achieved after the input of the 10 parameters $\left(q_{\max }, K_{s q}\right.$, 
Int. J. Environ. Sci. Tech., 6 (1), 69-76, Winter 2009

Table 3: Comparisons between EBM optimal results and reference data

\begin{tabular}{|c|c|c|c|c|c|c|}
\hline \multirow[t]{2}{*}{ Parameters } & \multicolumn{2}{|c|}{ Lee and Lin, 1999} & \multicolumn{2}{|c|}{ Woodard, 2001} & \multicolumn{2}{|c|}{ Qin, 1989} \\
\hline & ** R. D. & C. D. & R. D. & C. D. & R. D. & C. D. \\
\hline $\mathrm{q}_{\max }, 1 / \mathrm{d}$ & 2.30 & $2.30 *$ & 2.87 & $2.87 *$ & 3.50 & $3.50 *$ \\
\hline $\mathrm{K}_{\mathrm{sq}}, \mathrm{g} / \mathrm{L}$ & 0.15 & $0.15^{*}$ & 0.33 & $0.33^{*}$ & 0.31 & $0.31^{*}$ \\
\hline$\mu_{\max }, 1 / d$ & 0.61 & $0.61^{*}$ & 1.03 & $1.03^{*}$ & 1.4 & $1.4^{*}$ \\
\hline $\mathrm{K}_{\mathrm{s \mu}}, \mathrm{g} / \mathrm{L}$ & 0.12 & $0.12 *$ & 0.36 & $0.36^{*}$ & 0.25 & $0.25^{*}$ \\
\hline $\mathrm{Y}_{\mathrm{t}}, \mathrm{kg} / \mathrm{kg}$ & 0.50 & $0.50 *$ & 0.57 & $0.57 *$ & 0.50 & $0.50 *$ \\
\hline $\mathrm{SVI}, \mathrm{ml} / \mathrm{g}$ & 134 & $134^{*}$ & 50 & $50 *$ & 100 & $100^{*}$ \\
\hline $\mathrm{Q}_{\mathrm{o}}, \mathrm{m}^{3} / \mathrm{d}$ & 27,648 & $27,648 *$ & 1,136 & $1,136 *$ & 20,000 & $20,000 *$ \\
\hline $\mathrm{S}_{0}, \mathrm{~g} / \mathrm{L}$ & 0.24 & $0.24^{*}$ & 1.71 & $1.71^{*}$ & 0.20 & 0.20 * \\
\hline $\mathrm{S}_{\mathrm{ei}}, \mathrm{g} / \mathrm{L}$ & $\leqslant 0.020$ & $\leqslant 0.020^{*}$ & $\leqslant 0.050$ & $\leqslant 0.050 *$ & $\leqslant 0.020$ & $\leqslant 0.020 *$ \\
\hline $\mathrm{X}_{\mathrm{ei}}, \mathrm{g} / \mathrm{L}$ & $\leqslant 0.024$ & $\leqslant 0.020^{*}$ & $\leqslant 0.020$ & $\leqslant 0.020^{*}$ & $<0.020$ & $\leqslant 0.020 *$ \\
\hline$\mu, 1 / \mathrm{d}$ & 0.125 & 0.087 & - & 0.122 & - & 0.102 \\
\hline $\mathrm{q}, 1 / \mathrm{d}$ & 0.320 & 0.271 & - & 0.376 & - & 0.208 \\
\hline HRT, d & 0.20 & 0.19 & 0.50 & 0.46 & 0.22 & 0.21 \\
\hline SRT, d & 10.00 & 1.48 & 10.00 & 8.18 & 11.60 & 9.83 \\
\hline $\mathrm{Y}_{\mathrm{obs}}, \mathrm{kg} / \mathrm{kg}$ & 0.313 & 0.322 & - & 0.325 & - & 0.489 \\
\hline $\mathrm{K}_{\mathrm{d}}, 1 / \mathrm{d}$ & 0.060 & 0.048 & 0.056 & 0.092 & 0.050 & 0.0023 \\
\hline$X, g / L$ & 2.40 & 2.69 & 8.66 & 5.67 & 3.20 & 2.97 \\
\hline $\mathrm{X}_{\mathrm{s}}, \mathrm{g} / \mathrm{L}$ & 7.44 & 7.46 & 20.00 & 20.00 & 10.00 & 10.00 \\
\hline $\mathrm{X}_{\mathrm{r}}, \mathrm{g} / \mathrm{L}$ & 7.44 & 7.46 & 20.00 & 20.00 & 10.00 & 10.00 \\
\hline $\mathrm{M}_{\mathrm{t}}, \mathrm{kg} / \mathrm{d}$ & 1,676 & 1,263 & 409 & 360 & - & 1,251 \\
\hline $\mathrm{Q}_{\mathrm{r}}, \mathrm{kg} / \mathrm{d}$ & 13,112 & 15,352 & 954 & 842 & 9,240 & 8,283 \\
\hline $\mathrm{Q}_{\mathrm{s}}, \mathrm{kg} / \mathrm{d}$ & 270 & 230 & - & 18 & - & 157 \\
\hline $\mathrm{Q}_{\mathrm{e}}, \mathrm{kg} / \mathrm{d}$ & 27,266 & 27,418 & - & 1,118 & - & 19,843 \\
\hline $\mathrm{S}_{\mathrm{e}}, \mathrm{g} / \mathrm{L}$ & 0.006 & 0.020 & 0.004 & 0.049 & - & 0.020 \\
\hline$X_{e}, g / L$ & 0.0240 & $<0.001$ & - & $<0.001$ & - & $<0.001$ \\
\hline $\mathrm{V}_{\min }, \mathrm{m}^{3}$ & 5,586 & 5,834 & 568 & 519 & 4,400 & 4,139 \\
\hline Errors of $\mathrm{V}_{\min }$ & \multicolumn{2}{|c|}{$4.44 \%$} & \multicolumn{2}{|c|}{$8.63 \%$} & \multicolumn{2}{|c|}{$5.93 \%$} \\
\hline
\end{tabular}

Table 4: Regulation strategies of treatment system for purified terephthalic acid wastewater

\begin{tabular}{lll}
\hline Periods & Regulation types & Regulation factors \\
\hline Period (A) & Single-item regulation & Operation parameters such as $\mathrm{Q}_{0}, \mathrm{Q}_{\mathrm{r}}$ and $\mathrm{HRT}$ \\
Period (B) & Double-item regulation & Operation parameters and metallic ions $\mathrm{Mn}^{2+}, \mathrm{Cu}^{2+}, \mathrm{Zn}^{2+}$ and $\mathrm{Se}^{4+}$ \\
Period (C) & Three-item regulation & The above items and nutrition factors of nitrogen and phosphorus \\
Period (D) & Optimization regulation & Optimization regulation based on period (C) \\
\hline
\end{tabular}

Table 5: Comparisons between EBM optimal results and experimental data of pilot treatment system

\begin{tabular}{|c|c|c|c|c|c|c|c|}
\hline Parameters & E. D. & C. D. & Errors (\%) & Parameters & E. D. & C. D. & Errors (\%) \\
\hline $\mathrm{q}_{\max }, 1 / \mathrm{d}$ & 2.82 & $2.82 *$ & -- & SRT, d & 15.38 & 16.36 & 6.37 \\
\hline $\mathrm{K}_{\mathrm{sq}}, \mathrm{g} / \mathrm{L}$ & 0.39 & $0.39 *$ & -- & $\mathrm{Y}_{\mathrm{obs}}, \mathrm{kg} / \mathrm{kg}$ & 0.213 & 0.194 & 8.92 \\
\hline$\mu_{\max }, 1 / d$ & 0.56 & $0.56^{*}$ & -- & $\mathrm{K}_{\mathrm{d}}, 1 / \mathrm{d}$ & 0.069 & 0.077 & 11.59 \\
\hline $\mathrm{K}_{\mathrm{s \mu}}, \mathrm{g} / \mathrm{L}$ & 0.40 & $0.40 *$ & -- & $\mathrm{X}, \mathrm{g} / \mathrm{L}$ & 2.88 & 2.79 & 3.13 \\
\hline $\mathrm{Y}_{\mathrm{t}}, \mathrm{kg} / \mathrm{kg}$ & 0.44 & $0.44^{*}$ & -- & $\mathrm{X}_{\mathrm{s}}, \mathrm{g} / \mathrm{L}$ & 8.26 & 8.13 & 1.57 \\
\hline SVI, ml/g & 121 & $123^{*}$ & -- & $\mathrm{X}_{\mathrm{r}}, \mathrm{g} / \mathrm{L}$ & 8.26 & 8.13 & 1.57 \\
\hline $\mathrm{Q}_{\mathrm{o}}, \mathrm{m}^{3} / \mathrm{d}$ & 8.00 & $8.00 *$ & -- & $\mathrm{M}_{\mathrm{t}}, \mathrm{kg} / \mathrm{d}$ & 1.83 & 1.55 & 15.30 \\
\hline $\mathrm{S}_{0}, \mathrm{~g} / \mathrm{L}$ & 1.52 & $1.52 *$ & -- & $\mathrm{Q}_{\mathrm{r}}, \mathrm{m}^{3} / \mathrm{d}$ & 4.24 & 3.90 & 8.02 \\
\hline $\mathrm{S}_{\mathrm{e}}, \mathrm{g} / \mathrm{L}$ & $<0.050$ & $<0.050 *$ & -- & $\mathrm{Q}_{\mathrm{s}}, \mathrm{m}^{3} / \mathrm{d}$ & 0.22 & 0.19 & 13.64 \\
\hline $\mathrm{X}_{\mathrm{ei}}, \mathrm{g} / \mathrm{L}$ & $<0.070$ & $<0.070^{*}$ & -- & $\mathrm{Q}_{\mathrm{e}}, \mathrm{m}^{3} / \mathrm{d}$ & 7.78 & 7.81 & 0.39 \\
\hline$\mu, 1 / \mathrm{d}$ & 0.065 & 0.061 & 6.15 & $\mathrm{~S}_{\mathrm{e}}, \mathrm{g} / \mathrm{L}$ & 0.036 & 0.042 & 16.67 \\
\hline $\mathrm{q}, 1 / \mathrm{d}$ & 0.304 & 0.315 & 3.62 & $X_{e}, g / L$ & 0.010 & 0.003 & 70.00 \\
\hline HRT, d & 1.23 & 1.14 & 7.32 & $\mathrm{~V}_{\min }, \mathrm{m}^{3}$ & 9.84 & 9.21 & 6.40 \\
\hline
\end{tabular}

${ }^{*}$ EBM input data; ${ }^{* *}$ E. D.: Experimental data; ${ }^{* * *}$ C. D.: EBM computed data 
$\mu_{\max }, K_{s \mu}, Y_{t}, S V I, Q_{0}, S_{o}, S_{e i}$ and $X_{e j}$ ) into the model (Table 5). After comparisons between the two groups, it is found that among the 16 pairs of parameters, the errors of 11 pairs are less than $10 \%$, including $\mu$, q, HRT, SRT, $Y_{\text {obs }}, X$, $\mathrm{X}_{\mathrm{s}}, \mathrm{Q}_{\mathrm{r}}, \mathrm{S}_{\mathrm{e}}, \mathrm{Q}_{\mathrm{e}}$ and $\mathrm{V}_{\text {min }}$ and those of 4 pairs range from $10 \%$ to $17 \%$, including $\mathrm{K}_{\mathrm{d}}, \mathrm{M}_{\mathrm{t}}, \mathrm{Q}_{\mathrm{s}}$ and $\mathrm{S}_{\mathrm{e}}$. Only one parameter error $\left(\mathrm{X}_{\mathrm{e}}\right)$ is more than $17 \%$ which probably results from the EBM hypothesis that there is no biomass in the bioreactor influent. EBM optimal $\mathrm{V}_{\min }$ is obtained to be $9.21 \mathrm{~m}^{3}$ and $\mathrm{V}_{\min }$ error between optimization value and experimental result is only $6.40 \%$. Dependent on the waste amounts and microbial characteristics, the bioreactor volume is the most crucial parameters for the design of wastewater treatment system which exerts a great influence on other process parameters, including hydraulic retention time, recycled sludge rate and air supplies (Gu, 1993; Rivas et al., 2008). A good $V_{\text {min }}$ agreement results in small errors of other variables between calculated results and experimental results. Therefore, EBM can be used to forecast operational state of activated sludge process accurately and to regulate and optimize the treatment system successfully.

\section{Cost evaluation of wastewater treatment system}

EBM has been applied to economically evaluate the former treatment system (with bacterium YZ1 cultivated in the bioreactor to treat PTA wastewater) and the four operation periods of pilot treatment system (with functional strain Fhhh introduced into the bioreactor to improve degradation efficiency). As shown in Table 6, when influent flow arrives at 10,000 $\mathrm{m}^{3} / \mathrm{d}$, EBM optimal $\mathrm{V}_{\text {min }}, \mathrm{A}_{\mathrm{T}}, \mathrm{E}_{\mathrm{e}}$ and $\mathrm{E}_{\mathrm{f}}$ in the pilot treatment system are achieved to be $6,529 \mathrm{~m}^{3}, 553 \mathrm{~m}^{2}, 0.88 \mathrm{CNY} / \mathrm{m}^{3}$ and 6.19 million-CNY, respectively. However, the four parameters of former treatment system are obtained to be $86,383 \mathrm{~m}^{3}$,
3,401 $\mathrm{m}^{2}, 11.70 \mathrm{CNY} / \mathrm{m}^{3}$ and 46.4 million-CNY. EBM optimal $\mathrm{V}_{\min }, \mathrm{A}_{\mathrm{T}}, \mathrm{E}_{\mathrm{e}}$ and $\mathrm{E}_{\mathrm{f}}$ in the pilot treatment system are $7.56 \%, 16.26 \%, 7.52 \%$ and $13.35 \%$ in former treatment system and $19.36 \%, 6.24 \%, 19.26 \%$ and $16.40 \%$ in period (A), respectively in which the system has not been regulated by metallic ions and nutrition factors. The results demonstrate that Fhhh presents a more economical form than YZ1 in PTA wastewater treatment and metallic and nutritional factors play important roles in biodegradation of the pollutants by Fhhh (Zhang et al., 2006a). Biodegradabilities of pollutants by microorganisms vary greatly (Zhang et al., 2006b), Thus, the biodegradation kinetics parameters must be taken into account for both design and optimization of activated sludge process.

\section{ACKNOWLEDGMENTS}

This research was financially supported by International Foundation for Science (No. W/4215-1) and Nanjing University Innovative Foundation (2006071009). The authors also would like to thank Nanjing Yangtze wastewater treatment plant (Nanjing, China) for the support of the pilot experiment.

Nomenclature

$\begin{array}{ll}A_{T}, m^{2} & \begin{array}{l}\text { Area of secondary settler } \\ B O D_{5}\end{array} \\ C, m g / L & \begin{array}{l}\text { Biochemical oxygen demands for } 5 \\ \text { days }\end{array} \\ C_{s m(20)}, m g / L & \begin{array}{l}\text { Oxygen concentration in wastewater } \\ \text { Oxygen solubility in distilled water } \\ \text { at } 20^{\circ} \mathrm{C}\end{array} \\ E_{A}, 100 \% & \begin{array}{l}\text { Oxygen absorptivity } \\ E_{e}, C N Y / m^{3}\end{array} \\ \begin{array}{l}\text { Electricity costs of wastewater } \\ \text { treatment }\end{array} \\ E_{f}, \text { million-CNY } & \begin{array}{l}\text { Equipment costs of reactor and } \\ \text { settler }\end{array}\end{array}$

Table 6: Cost evaluation of different wastewater treatment systems

\begin{tabular}{|c|c|c|c|c|c|}
\hline Parameters & Former system & Period (A) & Period (B) & Period (C) & Period (D) \\
\hline Microorganisms & YZ1 & \multicolumn{4}{|c|}{ Fhhh } \\
\hline $\mathrm{Q}_{0}, \mathrm{~m}^{3} / \mathrm{d}$ & 10,000 & 10,000 & 10,000 & 10,000 & 10,000 \\
\hline $\mathrm{V}_{\min }, \mathrm{m}^{3}$ & 86,383 & 33,718 & 24,350 & 18,824 & 6,529 \\
\hline SVI, mL/g & 287 & 491 & 347 & 196 & 121 \\
\hline $\mathrm{X}_{\mathrm{s}}, \mathrm{mg} / \mathrm{L}$ & 3.14 & 2.06 & 3.05 & 5.76 & 8.13 \\
\hline $\mathrm{A}_{\mathrm{T}}, \mathrm{m}^{2}$ & 3,401 & 8,869 & 4,233 & 1,266 & 553 \\
\hline $\mathrm{V}_{\mathrm{d}}, \mathrm{m}^{3}$ & 1,066 & 1,869 & 1,524 & 645 & 363 \\
\hline $\mathrm{V}_{\mathrm{s}}, \mathrm{m}^{3}$ & 2,356 & 3,763 & 3,228 & 1,708 & 1,088 \\
\hline $\mathrm{R}, \mathrm{m}^{3} / \mathrm{h}$ & 243.8 & 95.2 & 68.7 & 53.1 & 18.4 \\
\hline $\mathrm{G}_{\mathrm{s}}, \mathrm{m}^{3} / \mathrm{y}$ & $7.12 \times 10^{7}$ & $2.78 \times 10^{7}$ & $2.01 \times 10^{7}$ & $1.55 \times 10^{7}$ & $5.38 \times 10^{6}$ \\
\hline $\mathrm{W}, \mathrm{kw} \cdot \mathrm{h} / \mathrm{y}$ & $3.56 \times 10^{6}$ & $1.39 \times 10^{6}$ & $1.00 \times 10^{6}$ & $7.76 \times 10^{5}$ & $2.69 \times 10^{5}$ \\
\hline $\mathrm{E}_{\mathrm{e}}, \mathrm{CNY} / \mathrm{m}$ & 11.70 & 4.57 & 3.30 & 2.55 & 0.88 \\
\hline $\mathrm{E}_{\mathrm{f}}$, million-CNY & 46.4 & 37.7 & 23.8 & 14.3 & 6.19 \\
\hline
\end{tabular}




\begin{tabular}{|c|c|}
\hline$G_{s}, m^{3} / y$ & Air supplies in bioreactor \\
\hline$H R T, d$ & Hydraulic retention time \\
\hline$K_{d}, L / d$ & Cell decay coefficient \\
\hline$K_{L}^{a} a_{(20)}, 1 / h$ & $\begin{array}{l}\text { Oxygen total transfer coefficient at } \\
20^{\circ} \mathrm{C}\end{array}$ \\
\hline$K_{s q}, g / L$ & Substrate concentration at one-half \\
\hline$K_{s \mu}, g / L$ & Substrate concentration at one-half \\
\hline$M_{t}, \mathrm{~kg} / \mathrm{d}$ & Total mass of sludge production \\
\hline$q, L / d$ & Specific degradation rate \\
\hline$q_{\max }, L / d$ & Maximum specific degradation rate \\
\hline$Q_{e}, m^{3} / d$ & Effluent flow \\
\hline$Q_{o}, m^{3} / d$ & Influent flow \\
\hline$Q_{r}, m^{3} / d$ & Return sludge flow \\
\hline$Q_{s}, m^{3} / d$ & Waste sludge flow \\
\hline$R, \mathrm{~kg} / \mathrm{h}$ & Oxygen absorbency in bioreactor \\
\hline$S, g / L$ & $\mathrm{BOD}_{5}$ concentration in bioreactor \\
\hline$S_{e}, g / L$ & Effluent soluble $\mathrm{BOD}_{5}$ concentration \\
\hline$S_{e i}, g / L$ & EBM input data of $S_{e}$ \\
\hline$S_{o}, g / L$ & Influent $\mathrm{BOD}_{5}$ concentration \\
\hline SRT, $d$ & Sludge retention time \\
\hline$S S, g / L$ & Suspended solids \\
\hline$S V I, m L / g$ & Sludge volumetric index \\
\hline$t, h$ & Microbial growth or degradation time \\
\hline$T_{d}, h$ & Sludge deposition time \\
\hline$T, h$ & Sludge settling time \\
\hline$V, m^{3}$ & Bioreactor volume \\
\hline$V_{d}, m^{3}$ & Deposition volume of settler \\
\hline$V_{\min }, m^{3}$ & Minimum volume of bioreactor \\
\hline$V_{s}, m^{3}$ & Total volume of settler \\
\hline$X, g / L$ & SS concentration in bioreactor \\
\hline$X_{e}, g / L$ & Effluent suspend solids \\
\hline$X_{e i}, g / L$ & EBM input data of $X_{e}$ \\
\hline$X_{o}, g / L$ & Influent suspend solids \\
\hline$X_{r}, g / L$ & Return SS concentration \\
\hline$X_{s}, g / L$ & Waste SS concentration \\
\hline$Y_{o b s}^{s}$ & Observed yield coefficient \\
\hline$Y_{t}$ & Theoretical yield coefficient \\
\hline$Z S V, m / \min$ & Zone sedimentation velocity \\
\hline$\alpha$ & $\mathrm{K}_{\mathrm{L}}$ a ratio \\
\hline$\beta$ & Oxygen solubility ratio \\
\hline$\lambda_{1}$ & Coefficient of settler $E_{f}$ \\
\hline$\lambda_{2}$ & Coefficient of bioreactor $E_{f}$ \\
\hline$\gamma_{1}$ & Exponential coefficient of settler $E_{f}$ \\
\hline & Exponentialcoefficientof bioreactor $\mathrm{E}_{\mathrm{f}}$ \\
\hline$\mu, L / d$ & Specific growth rate \\
\hline$\mu_{\max }, L / d$ & Maximum specific growth rate \\
\hline
\end{tabular}

\section{REFERENCES}

Chen, J. C.; Chang, N. B., (2008). Mining the fuzzy control rules of aeration in a submerged biofilm wastewater treatment process., Eng. Appl. Artif. Intel., 20 (7), 959-969.

Cheng, S. P.; Yan, J.; Hao, C. B.; Zhang, X. X.; Shi, L., (2002). Advancement of environmental biotechnology informatics, Environ. Pollut. Control Tech. Equipment, 3 (11), 92-94.

Cheng, S. P.; Zhang, X. X.; Shi, L.; Qu, M. M.; Zhou, T.; Hao, C. B.; Yan, J., (2003). Degradation kinetics for Fhhh strain in PTA wastewater., Chinese J. Environ., Sci, 24 (6), 116-120.

Choi, D. J.; Park, H. Y., (2001). A hybrid artificial neural network as a software sensor for optimal control of a wastewater treatment process., Water Res., 35 (16), 3959-3967.

Corbitt, R. A.; Crawford, H. B.; Gleason, D., (1998). Standard Handbook of Environmental Engineering, $2^{\text {nd }}$ (Ed.) McGrawHill Inc, New York, USA, 6-17.

Fu, G. W.; Cheng, S. T., (1985). Design of control system for water pollution, Tsinghua university press, Beijing, China, 77-78.

Gao, J. S.; Peng, Y. Z., (2004). Wastewater treatment systems: Modeling, diagnosis and control, chemical industry press, Beijing, China, 29-31.

Glover, G. C.; Printemps, C.; Essemiani, K.; Meinhold J., (2006). Modelling of wastewater treatment plants - how far shall we go with sophisticated modelling tools?, Water Sci. Tech., 53 (3), 79-89.

Gu, X. S., (1993). Mathematical Model for Biological Wastewater Treatment, Tsinghua university press, Beijing, China, 34-39.

Gujer, W., (2006). Activated sludge modelling: Past, present and future., Water Sci. Tech., 53 (3), 111-119.

Gujer, W.; Henze, M.; Mino, T.; Loosdrecht, M. V., (1999). Activated sludge model No. 3., Water Sci. Tech., 39 (1), 183193.

Hao, C. B.; Yan, J.; Qu, M. M.; Wang, D.; Cheng, S. P.; Gu, J. D.; Qiu, W. F.; Wang, Y. Y., (2003). Analysis of parental strain DNA fragments existing in GEMs-Fhhh., J. Environ. Sci., 15 (5), 590-594.

Hosseini, F.; Malekzadeh, F.; Amirniiozafari, N.; Ghaemi, N., (2007) Biodegradation of anionic surfactants by isolated bacteria from activated sludge., Int. J. Environ. Sci. Tech., 4 (1), 127-132.

Hu, Z. R.; Wentzel, M. C.; Ekama, G. A., (2007). A general kinetic model for biological nutrient removal activated sludge systems: Model evaluation, Biotechnol. Bioeng., 98 (6), 1259-1275.

IWA Task Group, (2000). Activated sludge models ASM 1, ASM 2, ASM 2D and ASM 3, Scientific and technical report No. 9, IWA Task Group on Mathematical Modelling IWA Publishing, London, UK.

Li, W. X.; Zhang, X. X.; Wu, B.; Sun, S. L.; Chen, Y. S.; Pan, W. Y.; Zhao, D. Y.; Cheng, S. P., (2008) A comparative analysis of environmental quality assessment methods for heavy metal-contaminated soils, Pedosphere, 18 (3), 344-352.

Lee, C. C.; Lin, S. D., (1999). Handbook of Environmental Engineering Calculations, McGraw-Hill Inc, New York, USA, 1.545-1.551.

Middleton, A. C.; Lawrence, A. W., (1974). Cost optimization of activated sludge systems., Biotechnol. Bioeng., 16 (6), 807-826.

Mino, T.; San Pedro, D. C.; Yamamoto, S.; Matsuo, T., (1997). Application of the IAWQ activated sludge model to nutrient removal process., Water Sci. Tech., 35 (8), 111-118.

Mohanan, S.; Maruthamuthu, S.; Muthukumar, N.; Rajesekar, A.; Palaniswamy, N., (2007). Biodegradation of palmarosa oil (green oil) by Serratia marcescens., Int. J. Environ. Sci. Tech., 4 (2), 279-283. 
Oda, T.; Yano, T.; Niboshi Y., (2006). Development and exploitation of a multipurpose CFD tool for optimisation of microbial reaction and sludge flow., Water Sci. Tech., 53 (3), 101-110.

Okubo, T.; Kubo, K.; Hosomi, M.; Murakami, A., (1994). A knowledge-based decision support system for selection smallscale waste-water treatment processes., Water Sci. Tech., 30 (2), 175-184.

Panjeshahi, M. H.; Ataei A., (2008). Application of an environmentally optimum cooling water system design in water and energy conservation., Int. J. Environ. Sci. Tech., 5 (2), 251-262.

Qin, L. Y., (1989). Biological treatment of wastewater, Tongji University Press, Shanghai, China, 55-71.

Rashidinejad, F.; Osanloo, M.; Rezai, B., (2008). An environmental oriented model for optimum cut-off grades in open pit mining projects to minimize acid mine drainage., Int. J. Environ. Sci. Tech., 5 (2), 183-194.

Reichert, P.; Von Schulthess, R.; Wild, D., (1995). The use of AQUASIM for estimating parameters of activated sludge models., Water Sci. Tech., 31 (2), 135-147.

Ribas, F.; Rodriguez-Roda, I.; Serrat, J.; Clara, P.; Comas, J., (2008). Development and implementation of an expert system to improve the control of nitrification and denitrification in the Vic wastewater treatment plant., Environ. Tech., 29 (5), 583-590.

Rivas, A.; Irizar, I.; Ayesa, E., (2008). Model-based optimisation of wastewater treatment plants design., Environ. Modell. Softw., 23 (4), 435-450.

Souza, S. M.; Araújo, O. Q. F.; Coelho, M. A. Z., (2008). Modelbased optimization of a sequencing batch reactor for biological nitrogen removal, Bioresource Tech., 99 (8), 3213-3223.
Sun, S. L.; Cheng, S. P.; Wan, Y. Q.; Zhang, X. X.; Shi, L.; Zhu, C. J.; Yu, H. X., (2005). Pilot regulation of MnP-SA to treat PTA wastewater, J. Environ. Sci., 17 (3), 375-378.

Suzuki, Y.; Takahashi, M.; Haesslein, M.; Seyfried, C. F., (1999). Development of simulation model for a combined activatedsludge and biofilm process to remove nitrogen and phosphorus., Water Environ. Res., 71 (4), 388-397.

Templeton, M. R.; Hofmann, R.; Andrews, R. C.; Whitby, G. E., (2006). Biodosimetry testing of a simplified computational model for the UV disinfection of wastewater., J. Environ. Eng. Sci., 5 (1), 29-36.

Von Sperling, M., (1994). Calibration of poorly identifiable systems - Application to activated sludge model., J. Environ. EngASCE, 120 (3), 625-644.

Woodard, F., (2001). Industrial waste treatment handbook. Butterworth-Heinemann Inc, Woburn, USA, 260-261.

Zeidan, A.; Rohani, S.; Bassi, A.; Whitting, P., (2003). BioSys: Software for wastewater treatment simulation., Adv. Eng. Softw., 34 (9), 539-549.

Zhang, X. X.; Cheng, S. P.; Sun, S. L.; Zhu, C. J.; Zhao, D. Y., (2006a). A pilot study on the biological treatment of PTA wastewater with functional strain Fhhh., Environ. Eng. Sci., 23 (6), 1065-1072.

Zhang, X. X.; Cheng, S. P.; Wan, Y. Q.; Sun, S.L.; Zhu, C. J.; Zhao, D. Y.; Pan, W. Y., (2006b). Degradability of five aromatic compounds in a pilot wastewater treatment system, Int. Biodeter. Biodegr., 58 (2), 94-98.

Zhang, X. X.; Wan, Y. Q.; Cheng, S. P.; Sun, S. L.; Zhu, C. J.; Li, W. X.; Zhang, X. C.; Wang, G. L.; Lu, J. H.; Luo, X.; Gu, J. D., (2005). Purified terephthalic acid wastewater biodegradation and toxicity., J. Environ. Sci., 17 (5), 876-880.

\section{AUTHOR (S) BIOSKETCHES}

Zhang, X. X., Assistant professor, State Key Laboratory of Pollution Control and Resource Reuse, School of The Environment, Nanjing University, Nanjing 210093, China. Email: zhangxx@nju.edu.cn

Zhao, D. Y., Ph.D. student, State Key Laboratory of Pollution Control and Resource Reuse, School of The Environment, Nanjing University, Nanjing 210093, China. Email: zhaodayong125016@gmail.com

Wang, Z. X., Ph.D. student, State Key Laboratory of Pollution Control and Resource Reuse, School of The Environment, Nanjing University, Nanjing 210093, China. Email: wzx1972@yahoo.com.cn

Wu, B., Ph.D. student, State Key Laboratory of Pollution Control and Resource Reuse, School of The Environment, Nanjing University, Nanjing 210093, China.Email: pandanju@gmail.com

Li, W. X., Professor, Nanjing Institute of Environmental Sciences, State Environmental Protection Administration of China, Nanjing 210042, China. Email: Iwxletter@yahoo.com.cn

Cheng, S. P., Professor, State Key Laboratory of Pollution Control and Resource Reuse, School of The Environment, Nanjing University, Nanjing 210093, China. Email: ebzxx0408@yahoo.com.cn 